\title{
Chemical signatures in the otoliths of a coastal marine fish, Menidia menidia, from the northeastern United States: spatial and temporal differences
}

\author{
Lora M. Clarke ${ }^{1,3, *}$, Benjamin D. Walther ${ }^{2,4}$, Stephan B. Munch ${ }^{1}$, \\ Simon R. Thorrold ${ }^{2}$, David O. Conover ${ }^{1}$ \\ ${ }^{1}$ Marine Sciences Research Center, Stony Brook University, Stony Brook, New York 11794-5000, USA \\ ${ }^{2}$ Biology Department MS \#50, Woods Hole Oceanographic Institution, Woods Hole, Massachusetts 02543, USA \\ ${ }^{3}$ Present address: NOAA Fisheries, 1315 East-West Highway, Silver Spring, Maryland 20910, USA \\ ${ }^{4}$ Present address: Marine Science Institute, The University of Texas at Austin, 750 Channel View Drive, Port Aransas, \\ Texas 78373, USA
}

\begin{abstract}
Knowledge of population structure in marine systems is fundamental to effective management and conservation. The geochemical signature of otoliths may provide a promising natural tag for quantifying population structure in marine fishes. However, the spatial scale at which chemical signatures differ among species from different environments and with different life histories is not yet clear. We examined chemical signatures in the otoliths of juvenile Menidia menidia, a ubiquitous nearshore marine species found along the east coast of North America that undergoes offshore winter migration. Specimens were collected from 16 locations in 2003 and from 9 locations in 2004 between New Jersey and Maine. Otolith geochemistry was analyzed using laser ablation inductively coupled plasma-mass spectrometry and isotope ratio mass spectrometry. Juvenile fish showed significant site-specific differences and were assigned to natal sites with $70 \%$ (2003) and $77 \%$ (2004) average cross-validated classification accuracies based on elemental $(\mathrm{Mg}, \mathrm{Mn}, \mathrm{Sr}, \mathrm{Ba}, \mathrm{Cu}$, and $\mathrm{Pb}$ relative to $\mathrm{Ca}$ ) and isotope $\left(\delta^{13} \mathrm{C}, \delta^{18} \mathrm{O}\right)$ ratios using quadratic discriminant function analysis. Geochemical signatures showed significant interannual variation, suggesting natural tags are year-class specific. Results suggest enough heterogeneity exists in marine chemical signatures to track movements and determine whether $M$. menidia return to their natal, nearshore location upon return from winter migration. Because M. menidia show evidence of local adaptation, knowledge of this winter migration will have evolutionary and ecological implications. Geochemical signatures of otoliths will likely serve as a useful tool in species with similar life histories.
\end{abstract}

KEY WORDS: Otolith chemistry · Menidia menidia · Population structure • Natural tag · Natal fingerprint

Resale or republication not permitted without written consent of the publisher

\section{INTRODUCTION}

Knowledge of population structure in marine systems is fundamental to effective management, conservation and understanding of ecological systems. Patterns of connectivity, or the exchange of individuals among sub-populations of a species, are an important consideration in biological oceanography, yet remain a mys- tery for many marine species. Until recently, the notion of large-scale marine dispersal leading to largely open, or highly connected, populations was widely accepted for most marine fish species (Swearer et al. 2002). There is a growing body of evidence that suggests these assumptions may not hold true for many marine populations. Studies reporting evidence of natal homing (Thorrold et al. 2001) and self-recruitment in coral reef 
fishes (Jones et al. 1999, Swearer et al. 1999, Cowen et al. 2006) suggest low connectivity. These findings cast doubt on our understanding of connectivity in marine populations and highlight the need for more research to facilitate further understanding of population structure.

Determining population connectivity in marine fishes can be difficult using conventional tagging methods due to the small size of juveniles, high mortality rates, and low tag returns (Gillanders 2002a). More recently, the elemental and stable isotope composition of otoliths has provided a promising method for quantifying rates of exchange. Otoliths are useful natural tags largely due to the manner in which they are formed. Calcium carbonate is laid down in sequential layers that are not subject to resorption, and otolith growth continues throughout the life of the fish (Thresher 1999). As the otolith forms, trace elements are incorporated into its calcium carbonate structure creating a chemical signature. In many cases, different natal habitats create distinctive otolith signatures, thus enabling researchers to determine natal origins of adult fish (Gillanders \& Kingsford 1996, Thorrold et al. 2001, Gillanders 2002a).

Differences in elemental signatures have been identified in fish from different estuaries (Thorrold et al. 1998b, Gillanders 2002b), rivers (Walther et al. 2008), reef habitats (Patterson et al. 2004), seagrass beds (Dorval et al. 2005), coastal areas (Campana et al. 1999, Warner et al. 2005), and oceanic regions (Ashford et al. 2005), thus supporting the idea that otoliths can be used as natural tags. The spatial scales at which habitats can be discriminated, however, is still being investigated and will likely differ among systems (see review Gillanders 2002b). While most work examining the usefulness of otolith geochemistry as a natural tag has focused on isolated habitats, such as rivers or estuaries, and large spatial scales, recent studies have been conducted that show promise at smaller spatial scales. Among estuaries, it is possible to discriminate habitats at spatial scales on the order of 100s of kilometers apart (Thorrold et al. 1998b, Gillanders 2002b, Patterson et al. 2004), and, more recently, on very fine spatial scales of approximately $15 \mathrm{~km}$ within estuaries (Dorval et al. 2005). Evidence of such discriminatory power in coastal or marine environments of fish not dependent on estuaries is still sparse. Warner et al. (2005) reported significant between-site discrimination of natal signatures in the otoliths of the kelp rockfish Sebastes atrovirens at spatial scales of 10 s of kilometers apart. Previous studies in coastal or open ocean systems have been limited to much larger spatial scales (Rooker et al. 2001, FitzGerald et al. 2004, Ashford et al. 2005, Humphreys et al. 2005).

While the population structure of many reef, estuarine, and anadromous fish species is gaining increased scrutiny, the usefulness of otoliths to detect population structure in marine species inhabiting more coastal and open ocean environments that lack clear geographic barriers is still not clear. Some fish species are continuously distributed and lack life stages that occur in isolated habitats. The Atlantic silverside Menidia menidia is a continuously and ubiquitously distributed coastal species found along the east coast of the United States. M. menidia exhibits nondispersive egg and larval stages found in nearshore habitats, but has a winter migratory phase that has the potential to lead to wide dispersal. Does enough chemical heterogeneity exist in the coastal marine environment to allow otolith geochemistry to be a useful natural tag in species with such life histories? Natal signatures must be distinctive if otolith geochemistry is to be successfully used to determine population structure. The purpose of the present study is to investigate the ability of otoliths to act as natural tags in a continuously distributed coastal fish species. Before questions concerning connectivity in this species, and others with similar life histories, can be addressed, the usefulness of geochemical signatures in the otoliths of juvenile $M$. menidia must first be determined.

\section{MATERIALS AND METHODS}

Study species. The Atlantic silverside Menidia menidia is one of the most abundant fish species in coastal and estuarine waters from Florida to Nova Scotia (Conover \& Ross 1982). Spawning occurs in the intertidal zone from mid-March through June in the midAtlantic region (Hillebrand 1928) and slightly later in northern populations (Conover \& Present 1990). Eggs are demersal and are attached to submerged vegetation (Middaugh 1981, Middaugh et al. 1981). Evidence from $\delta^{15} \mathrm{~N}$ in the tissue of $M$. menidia collected from Waquoit Bay, Massachusetts, demonstrated juveniles remain in their natal estuaries during their first growing season, thereby supporting the idea of low dispersal (Griffin \& Valiela 2001). Juveniles grow rapidly through the summer and nearly reach full size by fall. In the fall, northern populations of $M$. menidia migrate offshore and over-winter on the continental shelf (Conover \& Murawski 1982). Due to high winter mortality, a low percentage returns the following spring to spawn. M. menidia is essentially an annual species, with most individuals maturing at $1 \mathrm{yr}$ of age. Only a very small percentage $(<1 \%)$ survive to $2 \mathrm{yr}$ of age (Conover \& Ross 1982).

Sample collection. Juvenile Menidia menidia were collected with a 10 or $30 \mathrm{~m}$ beach seine from 3 sites within each of 16 different locations spanning $630 \mathrm{~km}$ from New Jersey to Maine in August/September 2003 
and from 9 of the same locations spanning approximately $350 \mathrm{~km}$ from New York to Massachusetts in August/September 2004 (Fig. 1, Table 1). The elimination of locations during the second field season was due to time and cost constraints. Locations consisted primarily of coastal embayments and estuaries along the coast. Sites within locations were separated by 5 to $10 \mathrm{~km}$ to ensure that the maximum range of environ-
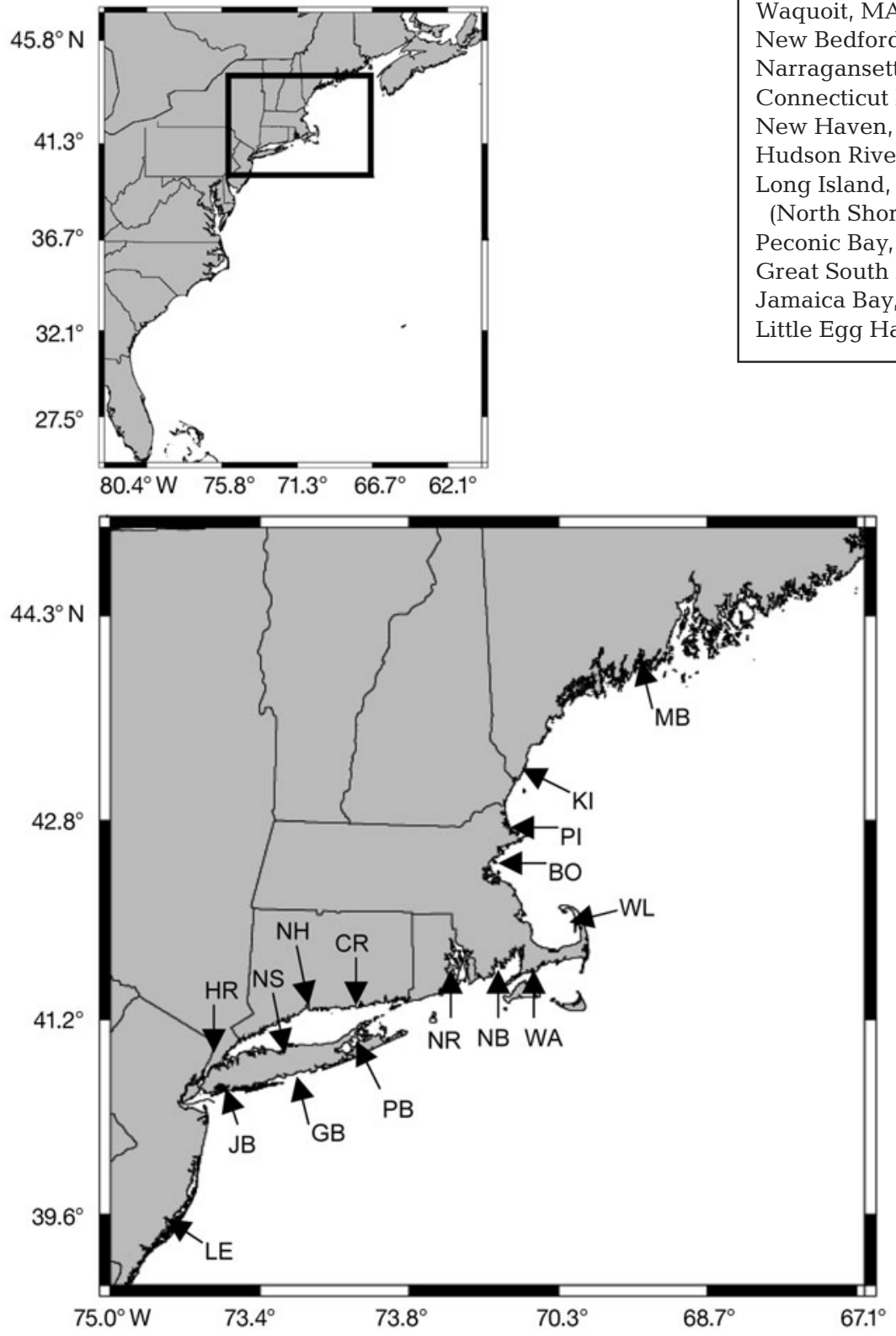

Fig. 1. Map of Menidia menidia sampling locations along the northeastern coast of the United States. LE: Great Bay/Little Egg Harbor, NJ; HR: Hudson River, NY; JB: Jamaica Bay, NY; GB: Great South Bay, NY; PB: Peconic Bay, NY; NS: the North Shore of Long Island, NY; NH: New Haven (Flax Pond, Setauket Harbor, and Mt. Sinai Harbor), CT; CR: Connecticut River, CT; NR: Narragansett Bay, RI; NB: New Bedford, MA; WA: Waquoit, MA; WL: Wellfleet, MA; PI: Plum Island, MA; BO: Boston Harbor, MA; KI: Kittery, ME; MB: Muscongus Bay, ME
Table 1. Sampling locations along the northeastern coast of the United States in 2003 and 2004

\begin{tabular}{|ll}
\hline 2003 & 2004 \\
\hline Muscongus Bay, ME & Waquoit, MA \\
Kittery, ME & Narragansett, RI \\
Plum Island, MA & Connecticut River, CT \\
Boston, MA & New Haven, CT \\
Wellfleet, MA & Hudson River, NY \\
Waquoit, MA & Long Island, NY \\
New Bedford, MA & (North Shore) \\
Narragansett Bay, RI & Peconic Bay, NY \\
Connecticut River, CT & Great South Bay, NY \\
New Haven, CT & Jamaica Bay, NY \\
Hudson River, NY & Little Egg Harbor, NJ \\
Long Island, NY & \\
(North Shore) & \\
Peconic Bay, NY & \\
Great South Bay, NY & \\
Jamaica Bay, NY & \\
Little Egg Harbor, NJ & \\
\hline
\end{tabular}

mental exposures experienced by an individual fish within the location was sampled. Annually, 10 juveniles were collected from each of the 3 sites within the location for a total of 30 fish location $^{-1}$. After collection, fish were kept on ice in the field and frozen upon return to the laboratory.

Otolith preparation. Sagittal otoliths were removed, cleaned of adhering tissue with Milli-Q ultrapure water, and air-dried. One randomly selected otolith from each fish was then prepared for trace element analysis. This otolith was mounted on a microscope slide and ground to the core using fine-grain lapping paper. Final preparation stages were conducted on a Class 100 clean bench under a laminar flow hood. Otoliths were triple rinsed with Milli-Q water, gently scrubbed with a nylon brush, triple rinsed with Milli-Q again, and then sonicated for 2 min. After sonication, otoliths were rinsed with Milli-Q and allowed to dry for $24 \mathrm{~h}$ under the laminar flow hood. Otoliths were then mounted to clean petrographic slides using double-sided tape, sealed in plastic Petri dishes, and transported to the inductively coupled plasma-mass spectrometer (ICP-MS) laboratory at the Woods Hole Oceanographic Institution (WHOI), Massachusetts, USA. 
The matching otolith from each pair was prepared for whole otolith stable isotope analysis. Otoliths were triple rinsed with Milli-Q water, sonicated for 2 min, rinsed with Milli-Q again, and allowed to dry under the laminar flow hood for $24 \mathrm{~h}$. Otoliths were then stored in dry plastic vials.

Otolith analysis. We analyzed $\mathrm{Mg} / \mathrm{Ca}, \mathrm{Mn} / \mathrm{Ca}, \mathrm{Cu} /$ $\mathrm{Ca}, \mathrm{Sr} / \mathrm{Ca}, \mathrm{Ba} / \mathrm{Ca}$, and $\mathrm{Pb} / \mathrm{Ca}$ from 1 randomly selected otolith per fish using a $213 \mathrm{~nm}$ New Wave laser ablation system coupled to a Thermo Finnigan Element 2 ICPMS. These elements have been shown to vary among sites and have previously been used as stock delineators (Thorrold et al. 1998b, Forrester \& Swearer 2002, Swearer et al. 2003); preliminary analysis showed that these elements were consistently found at levels above detection limits in the Menidia menidia otoliths. The laser traced out a $250 \mu \mathrm{m} \times 250 \mu \mathrm{m}$ raster with $50 \mu \mathrm{m}$ spacing centered on the otolith core. This area covered most of the juvenile otolith surface, but the laser was used, rather than a whole otolith approach for this analysis, to ensure consistency in techniques during later studies involving adult $M$. menidia. Laser spot size was $55 \mu \mathrm{m}$, scan speed was set at $10 \mu \mathrm{m} \mathrm{s}^{-1}$, and repetition rate was $10 \mathrm{~Hz}$. We quantified ${ }^{25} \mathrm{Mg},{ }^{43} \mathrm{Ca},{ }^{55} \mathrm{Mn}$, ${ }^{63} \mathrm{Cu},{ }^{86} \mathrm{Sr},{ }^{138} \mathrm{Ba}$, and ${ }^{208} \mathrm{~Pb}$ during each sample run. Instrument blanks of $2 \% \mathrm{HNO}_{3}$ were run at the beginning, middle, and end of a block of 10 otoliths, and were linearly interpolated. Dissolved otolith certified reference material (CRM) (Yoshinaga et al. 2000) was used to correct for instrument mass bias (Rosenthal et al. 1999), and instrument precision was assessed using a second type of otolith CRM (Sturgeon et al. 2005). Detection limits were calculated as 3 standard deviations of the blanks that were run throughout the analyses ( $\mathrm{n}=219)$. These limits were $4.01 \%$ of the average intensity for $\mathrm{Mg}, 0.57 \%$ for $\mathrm{Ca}, 6.71 \%$ for $\mathrm{Mn}, 15.91 \%$ for $\mathrm{Cu}, 0.19 \%$ for $\mathrm{Sr}, 0.81 \%$ for $\mathrm{Ba}$, and $16.46 \%$ for $\mathrm{Pb}$. External precision values (relative standard deviations) for the second CRM ( $\mathrm{n}=146$ ) were $7.13 \%$ for $\mathrm{Mg} / \mathrm{Ca}$, $12.52 \%$ for $\mathrm{Mn} / \mathrm{Ca}, 7.81 \%$ for $\mathrm{Cu} / \mathrm{Ca}, 2.10 \%$ for $\mathrm{Sr} / \mathrm{Ca}$, $2.80 \%$ for $\mathrm{Ba} / \mathrm{Ca}$, and $8.86 \%$ for $\mathrm{Pb} / \mathrm{Ca}$.

The remaining whole otolith was used to determine $\delta^{13} \mathrm{C}$ and $\delta^{18} \mathrm{O}$ signatures. Whole otoliths could be used in this situation because we were interested in the 'juvenile' signature and not only the core. Stable isotopes were measured using a Finnigan MAT253 stable isotope ratio mass spectrometer located in the micropaleontology laboratory at WHOI. Otoliths were crushed with a mortar and pestle, and approximately 50 to $75 \mu \mathrm{g}$ of the otolith material was weighed and analyzed. Analytical methods followed those outlined by Ostermann \& Curry (2000). Isotopic values were reported relative to Vienna Pee Dee belemnite (VPDB) and expressed in standard $\delta$ notation. The long-term precision estimate of the mass spectrometer based on analyses of National
Bureau of Standards (NBS19) is \pm 0.07 for $\delta^{18} \mathrm{O}$ and \pm 0.03 for $\delta^{13} \mathrm{C}$ (Ostermann \& Curry 2000).

Statistical analysis. Elemental signatures were expressed as ratios to $\mathrm{Ca}$, to account for fluctuations in the amount of material ablated (Sinclair et al. 1998). All data were transformed using Box-Cox transformations in Minitab to improve normality. Minitab uses a Fibonacci search to find the smallest standard deviation and thus the best transformation. Lambda values for Box-Cox transformations were: -0.034 (Mg/Ca), -0.113 (Mn/Ca), $0.000(\mathrm{Cu} / \mathrm{Ca}), 1.572(\mathrm{Sr} / \mathrm{Ca}), 0.057$ $(\mathrm{Ba} / \mathrm{Ca}),-0.112(\mathrm{~Pb} / \mathrm{Ca}), 0.449\left(\delta^{13} \mathrm{C}\right)$, and $-0.056\left(\delta^{18} \mathrm{O}\right)$.

Elemental differences among sites within a location were tested for using a multi-variance analysis of variance (MANOVA) with site nested within location. Then, to address whether geochemical signatures varied geographically among sites and temporally among years, we used a 2-way MANOVA with site and year as factors. This also allowed us to test for an interaction between the 2 factors. Because the primary question was whether geochemical signatures differed by location and time, we pooled sites within locations. Furthermore, only sites that were sampled in both years were included in this analysis. For MANOVA tests, Pillai's trace was used as the test statistic, because it is more robust for both smaller and unequal sample sizes, as well as unequal covariance matrices (Scheiner 2001).

We tested the ability of geochemical signatures in otoliths to classify juvenile fish to their natal location using quadratic discriminant function analysis (QDFA) with leave-one-out cross validation. QDFA does not assume homogeneity of the covariance matrices and, therefore, was the chosen classification method (Krzanowski 1988).

\section{RESULTS}

Values for each element were within the range of those reported in other studies (Fig. 2). For 4 ICP-MS runs on the 2003 otoliths ( $\mathrm{n}=40$ otoliths), $\mathrm{Pb} / \mathrm{Ca}$ values were negative after the blank run values were subtracted and final $\mathrm{Pb} / \mathrm{Ca}$ ratios were calculated. The $\mathrm{Pb}$ content of the blank samples was nearly twice as high as the sample values. We had to eliminate these samples completely from the data analysis due to possible contamination.

\section{Spatial differences in otolith signatures}

Juvenile Menidia menidia otoliths showed significant geographic differences in chemistry along the northeast coast of the United States. MANOVA showed multivariate chemical otolith signatures were significantly 

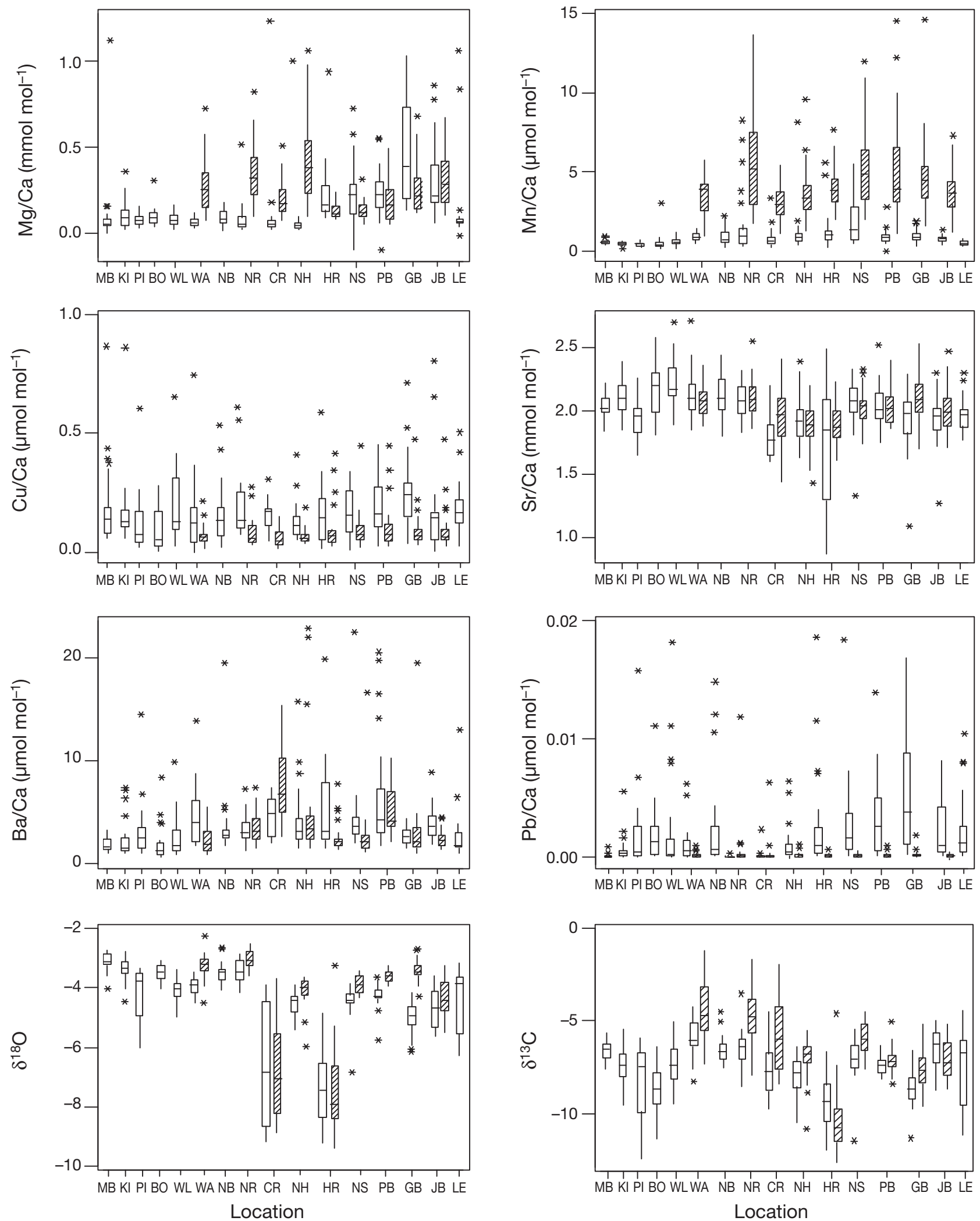

Fig. 2. Box plots of each otolith chemical per location. Open boxes: 2003 values; hatched boxes: 2004 values. The center line of each box represents the median; the top and bottom of the box indicate the 25th and 75th percentiles, respectively, and the whiskers indicate the range. Asterisks denote outliers 
different among locations (Table 2). Furthermore, the univariate output of the MANOVA provided by Statistica showed that significant among-location differences existed for all 8 variables analyzed (Table 3). Additionally, juvenile $M$. menidia otoliths showed significant differences in chemistry for sites nested within locations (Table 4). These differences existed for all variables, except $\mathrm{Cu} / \mathrm{Ca}$ and $\mathrm{Sr} / \mathrm{Ca}$ (the latter is just barely non-significant with a p-value of 0.053; Table 5).

Some further general overall patterns were observed within the data (Fig. 2). For example, Mg/Ca ratios tended to be highest in the locations around Long Island, New York; $\mathrm{Cu} / \mathrm{Ca}$ ratios were highest in the 3 riverine locations (Hudson River, Connecticut River, and Muscongus Bay, fed by the Medomak River); and $\mathrm{Mn} / \mathrm{Ca}$ ratios were lowest north of Cape Cod. Oxygen isotope values were lowest in fish from the sites with the lowest salinities, the Hudson and Connecticut Rivers, for both years. Carbon isotope values were also lowest in the Hudson River, for both years.

\section{Temporal differences in otolith signatures}

Multivariate otolith geochemical signatures showed significant temporal differences between 2003 and 2004 and significant location $\times$ year interactions were detected (Table 2). Furthermore, the univariate output of the MANOVA run in Statistica showed significant year effects were present for each of the 8 variables examined, and location $\times$ year interactions were significant for 6 of the 8 variables (Table 3). While $\mathrm{Cu} / \mathrm{Ca}$ and $\mathrm{Mn} / \mathrm{Ca}$ ratios showed significant differences among location and years, location $\times$ year interactions were not significant (although the p-value for $\mathrm{Mn} / \mathrm{Ca}$ was just barely non-significant at $\mathrm{p}=0.063$; Table 3 ).

$\mathrm{Mn} / \mathrm{Ca}$ and $\mathrm{Cu} / \mathrm{Ca}$ values were higher in 2004 than in 2003 , for all locations. $\delta^{18} \mathrm{O}$ values were generally higher in 2004 than in 2003, but values recorded in fish from the Connecticut and Hudson Rivers remained similar between years. $\mathrm{Pb} / \mathrm{Ca}$ values increased in 2004 in most locations, but were lower in Narragansett and roughly equivalent in the Connecticut River. $\mathrm{Mg} / \mathrm{Ca}, \mathrm{Sr} / \mathrm{Ca}$, $\mathrm{Ba} / \mathrm{Ca}$, and $\delta^{13} \mathrm{C}$ values increased at some sites and decreased at others, displaying no overall patterns (Fig. 2).

Table 2. Menidia menidia. Results of MANOVA examining spatial and temporal differences in the otolith chemistry of juveniles using pooled locations

\begin{tabular}{|lcccc|}
\hline & Test & $F$ & $\mathrm{df}$ & $\mathrm{p}$ \\
\hline Location & Pillai's & 22.7 & 56 & 0.000 \\
Year & Pillai's & 195 & 7 & 0.000 \\
Location $\times$ Year & Pillai's & 10.9 & 168 & 0.000 \\
\hline
\end{tabular}

Table 3. Menidia menidia. Univariate results of MANOVA using pooled locations examining spatial and temporal diffe-rences in otolith chemistry of juveniles

\begin{tabular}{|c|c|c|c|c|}
\hline & df & MS & $F$ & $\mathrm{p}$ \\
\hline \multicolumn{5}{|l|}{$\mathrm{Mg} / \mathrm{Ca}$} \\
\hline Location & 8 & 389.88 & 30.17 & 0.000 \\
\hline Year & 1 & 1988.56 & 153.90 & 0.000 \\
\hline Location $\times$ Year & 8 & 766.73 & 59.34 & 0.000 \\
\hline Error & 476 & 12.92 & & \\
\hline \multicolumn{5}{|l|}{$\mathrm{Mn} / \mathrm{Ca}$} \\
\hline Location & 8 & 0.53 & 5.7 & 0.000 \\
\hline Year & 1 & 71.40 & 772.2 & 0.000 \\
\hline Location $\times$ Year & 8 & 0.17 & 1.9 & 0.063 \\
\hline Error & 476 & 0.09 & & \\
\hline \multicolumn{5}{|l|}{$\mathrm{Cu} / \mathrm{Ca}$} \\
\hline Location & 8 & 1.45 & 2.4 & 0.016 \\
\hline Year & 1 & 56.76 & 92.8 & 0.000 \\
\hline Location $\times$ Year & 8 & 0.91 & 1.5 & 0.161 \\
\hline Error & 476 & 0.61 & & \\
\hline \multicolumn{5}{|l|}{$\mathrm{Sr} / \mathrm{Ca}$} \\
\hline Location & 8 & 0.00 & 13.81 & 0.000 \\
\hline Year & 1 & 0.00 & 6.21 & 0.013 \\
\hline Location $\times$ Year & 8 & 0.00 & 2.78 & 0.005 \\
\hline Error & 476 & 0.00 & & \\
\hline \multicolumn{5}{|l|}{$\mathrm{Ba} / \mathrm{Ca}$} \\
\hline Location & 8 & 0.00 & 17.0 & 0.000 \\
\hline Year & 1 & 0.01 & 23.7 & 0.000 \\
\hline Location $\times$ Year & 8 & 0.00 & 7.1 & 0.000 \\
\hline Error & 476 & 0.00 & & \\
\hline \multicolumn{5}{|l|}{$\mathrm{Pb} / \mathrm{Ca}$} \\
\hline Location & 8 & 27.52 & 17.27 & 0.000 \\
\hline Year & 1 & 378.66 & 237.69 & 0.000 \\
\hline Location $\times$ Year & 8 & 26.56 & 16.67 & 0.000 \\
\hline Error & 476 & 1.59 & & \\
\hline \multicolumn{5}{|l|}{$\delta^{13} \mathrm{C}$} \\
\hline Location & 8 & 2.43 & 65.09 & 0.000 \\
\hline Year & 1 & 2.07 & 55.33 & 0.000 \\
\hline Location $\times$ Year & 8 & 0.35 & 9.41 & 0.000 \\
\hline Error & 476 & 0.04 & & \\
\hline \multicolumn{5}{|l|}{$\delta^{18} \mathrm{O}$} \\
\hline Location & 8 & 0.20 & 185.29 & 0.000 \\
\hline Year & 1 & 0.14 & 136.63 & 0.000 \\
\hline Location $\times$ Year & 8 & 0.01 & 12.16 & 0.000 \\
\hline Error & 476 & 0.00 & & \\
\hline
\end{tabular}

Table 4. Menidia menidia. Results of MANOVA examining differences in otolith chemistry of juveniles collected at sites nested with locations

\begin{tabular}{|lcccc|}
\hline & Test & $F$ & $\mathrm{df}$ & $\mathrm{p}$ \\
\hline Location & Pillai's & 20.0 & 56 & 0.000 \\
Site (Location) & Pillai's & 4.54 & 168 & 0.000 \\
\hline
\end{tabular}


Table 5. Menidia menidia. Univariate results of MANOVA examining differences in otolith chemistry of juveniles collected from sites nested within locations

\begin{tabular}{|c|c|c|c|c|}
\hline & df & MS & $F$ & $\mathrm{p}$ \\
\hline \multicolumn{5}{|l|}{$\mathrm{Mg} / \mathrm{Ca}$} \\
\hline Location & 8 & 322.000 & 16.071 & 0.000 \\
\hline Year & 1 & 167.200 & 8.344 & 0.004 \\
\hline Site(Location) & 24 & 127.800 & 6.380 & 0.000 \\
\hline Error & 460 & 20.000 & & \\
\hline \multicolumn{5}{|l|}{$\mathrm{Mn} / \mathrm{Ca}$} \\
\hline Location & 8 & 0.463 & 5.070 & 0.000 \\
\hline Year & 1 & 52.736 & 577.720 & 0.000 \\
\hline Site(Location) & 24 & 0.142 & 1.550 & 0.047 \\
\hline Error & 460 & 0.091 & & \\
\hline \multicolumn{5}{|l|}{$\mathrm{Cu} / \mathrm{Ca}$} \\
\hline Location & 8 & 1.300 & 2.100 & 0.037 \\
\hline Year & 1 & 39.100 & 63.500 & 0.000 \\
\hline Site(Location) & 24 & 0.600 & 1.000 & 0.418 \\
\hline Error & 460 & 0.600 & & \\
\hline \multicolumn{5}{|l|}{$\mathrm{Sr} / \mathrm{Ca}$} \\
\hline Location & 8 & 0.000 & 12.990 & 0.000 \\
\hline Year & 1 & 0.000 & 11.290 & 0.001 \\
\hline Site(Location) & 24 & 0.000 & 1.530 & 0.053 \\
\hline Error & 460 & 0.000 & & \\
\hline \multicolumn{5}{|l|}{$\mathrm{Ba} / \mathrm{Ca}$} \\
\hline Location & 8 & 0.004 & 16.000 & 0.000 \\
\hline Year & 1 & 0.008 & 36.300 & 0.000 \\
\hline Site(Location) & 24 & 0.001 & 3.200 & 0.000 \\
\hline Error & 460 & 0.000 & & \\
\hline \multicolumn{5}{|l|}{$\mathrm{Pb} / \mathrm{Ca}$} \\
\hline Location & 8 & 23.550 & 13.390 & 0.000 \\
\hline Year & 1 & 457.500 & 260.080 & 0.000 \\
\hline Site(Location) & 24 & 6.730 & 3.830 & 0.000 \\
\hline Error & 460 & 1.760 & & \\
\hline \multicolumn{5}{|l|}{$\delta^{13} \mathrm{C}$} \\
\hline Location & 8 & 2.463 & 72.500 & 0.000 \\
\hline Year & 1 & 0.931 & 27.410 & 0.000 \\
\hline Site(Location) & 24 & 0.206 & 6.070 & 0.000 \\
\hline Error & 460 & 0.034 & & \\
\hline \multicolumn{5}{|l|}{$\delta^{18} \mathrm{O}$} \\
\hline Location & 8 & 0.184 & 206.310 & 0.000 \\
\hline Year & 1 & 0.158 & 176.370 & 0.000 \\
\hline Site(Location) & 24 & 0.008 & 9.080 & 0.000 \\
\hline Error & 460 & 0.001 & & \\
\hline
\end{tabular}

\section{Classification of juvenile fish to natal habitat}

Results of the QDFA with leave-one-out cross validation showed that the original spatial scale of our study (approximately $50 \mathrm{~km}$ between sites) was too small to allow for accurate classification of juvenile fish back to their site of origin, with overall error rates of $42 \%$ in 2003 and $38 \%$ in 2004 . We therefore pooled locations according to geographic region; this allowed locations to be discriminated at spatial distances of 50 to $125 \mathrm{~km}$ apart. Locations were grouped based on their proximity to one another and assumed natural geographic breaks. For example, sites within Long Island Sound were pooled together, and those on the south shore of Long Island were pooled. It is possible that such pooling may artificially inflate classification accuracy, so we have chosen to report both the pooled and unpooled results.

After pooling, the original 16 locations of 2003 were merged into 9 locations, which could be classified with $70 \%$ overall accuracy (Table 6). In 2004, with fewer sites, classification accuracy of the pooled sites increased to $77 \%$ (Table 6). Moreover, restriction of the discriminant function to include only those 2003 sites that were also sampled in 2004 showed classification accuracy increased to $84 \%$. Addition of the stable isotopes to the discriminant function greatly increased classification accuracies. Without the carbon and oxygen isotope data the cross-validated accuracies for the original locations were $44 \%$ (2003) and 36\% (2004). Classification accuracies without the isotope values for the pooled locations were $47 \%$ (2003) and $40 \%$ (2004).

Classification schemes derived from the discriminant functions also differed between years. When the 2004 fish were classified back to original locations using the 2003 discriminant function, error rates were $40.7 \%$ using original locations and $28 \%$ using pooled locations. When 2003 fish were classified back to original locations using the 2004 discriminant functions, error rates were $71 \%$ using original locations and

Table 6. Menidia menidia. Percentage of juveniles correctly classified to their juvenile location after pooling using quadratic discriminant function analyses with leave-one-out cross validation performed separately for 2003 and 2004 samples

\begin{tabular}{|lc|}
\hline Location & \% correct \\
\hline $\mathbf{2 0 0 3}$ & \\
Muscongus & 78.3 \\
Kittery, Plum Island, Boston & 66.7 \\
Wellfleet & 56.0 \\
Waquoit Bay, New Bedford, Narragansett & 60.9 \\
Connecticut River & 80.0 \\
New Haven, North Shore & 64.0 \\
Jamaica Bay, Great South Bay, Peconic Bay & 74.7 \\
Hudson River & 89.3 \\
Little Egg Harbor & 60.7 \\
Mean & 70.1 \\
& \\
2004 & \\
Waquoit Bay, Narragansett & 83.3 \\
Connecticut River & 86.7 \\
New Haven, North Shore & 71.7 \\
Jamaica Bay, Great South Bay, Peconic Bay & 71.1 \\
Hudson River & 86.7 \\
Mean & 77.4 \\
\hline
\end{tabular}


$56 \%$ using pooled locations. Only geochemical signatures from Hudson River fish remained sufficiently stable throughout the $2 \mathrm{yr}$ period to allow for the 2004 fish to be classified using the 2003 discriminant function. Accuracy was $76.7 \%$ using both the original and pooled locations for the 2004 Hudson River fish using the 2003 discriminant function.

\section{DISCUSSION}

\section{Spatial differences}

Geochemical signatures of juvenile Menidia menidia otoliths collected from locations along the northeastern coast of the United States showed significant differences among geographically separated locations. Using these signatures, juvenile fish could be classified back to their site of origin with $70 \%$ (2003) and $77 \%$ (2004) average cross-validated accuracy after pooling some of the original locations. Our results suggest there is sufficient chemical heterogeneity at relatively small spatial scales (50 to $125 \mathrm{~km}$ ) in the marine coastal environment for otoliths to be useful tools for investigating population structure in coastal systems.

The classification accuracies achieved in this study are similar to other studies that have examined fish collected in estuarine and riverine systems. For example, Gillanders \& Kingsford (2000) reported $75 \%$ accuracy examining the estuarine nursery habitats of juvenile trumpeter Pelates sexineatus, and Patterson et al. (2004) achieved $81 \%$ overall cross-validated classification accuracy while examining the juvenile signatures of red drum Sciaenops ocellatus collected from estuaries in the southeastern United States. Other researchers have reported even greater success. For example, Thorrold et al. (1998b) achieved nearly $90 \%$ classification accuracy when investigating juvenile signatures of estuarine-dependent weakfish, and Walther et al. (2008) reported classification accuracies of $91 \%$ in anadromous American shad Alosa sapidissima. The species investigated in the current study, $M$. menidia, differs from that in most other studies in that it is continuously distributed and does not have the clearly defined geographic borders for various life-history stages, such as spawning, that exist in other species.

Few studies have examined the usefulness of otoliths in coastal environments, and the success levels of these studies have varied. Warner et al. (2005) reported overall classification accuracies of 82.9 and $70.1 \%$ during a 2 yr study examining the otolith signatures of larval rockfish Sebastes atrovirens taken from nearterm females off the coast of California. Other studies examining differences in coastal or open-ocean environments have largely been confined to larger spatial scales (Rooker et al. 2001, FitzGerald et al. 2004, Humphreys et al. 2005).

Sample locations in the present study represented a range of habitats with differing environmental characteristics. In general, the northeast coast of the United States is a highly populated, industrial area, with numerous anthropogenic and natural activities influencing coastal waters (Buck et al. 2005). Locations sampled in our study ranged from areas bordering large metropolitan areas, such as the Hudson River, NY; Jamaica Bay, NY; and Boston, MA, to relatively pristine areas, at least by comparison, such as Great Bay/Little Egg Harbor, NJ, and Muscongus Bay, ME. Such differences may have accounted for the spatial scale at which chemical differences were able to be detected.

Our results show that $\mathrm{Mg} / \mathrm{Ca}, \mathrm{Mn} / \mathrm{Ca}, \mathrm{Sr} / \mathrm{Ca}, \mathrm{Ba} / \mathrm{Ca}$, $\delta^{18} \mathrm{O}$, and $\delta^{13} \mathrm{C}$ showed significant differences among locations in both years of the study. Two other elements measured, $\mathrm{Cu} / \mathrm{Ca}$ and $\mathrm{Pb} / \mathrm{Ca}$, showed significant differences in 2003, but not in 2004. Differences in geochemical signatures of juvenile otoliths were also found among sites within locations, demonstrating differences exist on very small spatial scales. Sites within locations were located within approximately 5 to $10 \mathrm{~km}$ of each other. Such small-scale differences have also been identified in other studies (Thorrold et al. 1998a,b, Hamer et al. 2003, Dorval et al. 2005). It is possible that these small-scale differences observed in Menidia menidia otoliths reflect small-scale differences in water chemistry among sites. Regardless of the underlying reason for such differences, fish were able to be classified by location of origin, suggesting that among-location differences were more important than within-location effects.

Use of carbon and oxygen stable isotopes greatly increased the classification accuracy of the quadratic discriminant function analysis. Oxygen isotopes are generally considered to be deposited in isotopic equilibrium with the ambient water and, therefore, to accurately reflect values in the environment in which the fish resided during deposition of the analyzed material (Kalish 1991a, Thorrold et al. 1997). Fractionation of carbon isotopes, however, appears to be more complicated. Otoliths typically incorporate carbon primarily from dissolved inorganic carbon, with a smaller contribution from metabolic sources (Thorrold et al. 1997). Physiological effects, including growth rate and maturation state, may influence the relative contribution of these 2 sources, and this will, in turn, generate differences in $\delta^{13} \mathrm{C}$ values (e.g. Schwarcz et al. 1998). Menidia menidia exhibits latitudinal differences in growth rate, such that fish from northern latitudes grow faster than those from southern latitudes (Conover \& Present 1990). Furthermore, growth efficiency 
(Present \& Conover 1992) and energy allocation (Billerbeck et al. 2000) have been shown to covary with growth along this latitudinal gradient. Although no clear latitudinal trend was evident in the data, such metabolic differences may influence $\delta^{13} \mathrm{C}$ values in $M$. menidia and contribute to the observed spatial differences. It is also possible that observed differences are a result of age and habitat use differences among locations. All juvenile fish were young-of-the-year, but latitudinal differences in spawning period (Conover \& Present 1990) can create age differences, which potentially contribute to differences in otolith chemistry.

\section{Physiological differences}

Elemental signatures of various fish species have also been shown to be correlated with physiological factors. For example, strontium incorporation has been suggested to be influenced by growth (Sadovy \& Severin 1992, 1994) and maturation (Kalish 1989, 1991b, Friedland et al. 1998). It is important to note that these relationships are not clear, and $\mathrm{Sr} / \mathrm{Ca}$ has also been frequently shown to be influenced by a variety of factors, including chemistry (Bath et al. 2000), diet (Kennedy et al. 2000, Buckel et al. 2004), and temperature (Martin et al. 2004). Although not as frequently studied as strontium, magnesium and manganese have also been reported to be influenced by otolith accretion rates and fish metabolism (Hamer \& Jenkins 2007). Furthermore, although there is little evidence to date on the influence of physiological effects on copper deposition, the bulk of copper measured in otoliths is associated with the protein matrix, suggesting that physiological influences are likely (Miller et al. 2006).

While there is much ambiguity concerning factors influencing otolith chemistry in the literature, the presence of well-documented physiological differences, such as growth rate (Conover \& Present 1990), growth efficiency (Present \& Conover 1992), and energy allocation (Billerbeck et al. 2000) among Menidia menidia populations likely contributes to observed spatial differences. Original sampling of these traits was conducted at intervals of 300 to $400 \mathrm{~km}$, but recent work shows that differences in growth rate differ at scales of approximately $50 \mathrm{~km}$ (minimum distance examined) along the east coast of the United States (D. Conover unpubl. data). Many of the sites used in our otolith study were also used in that study. Furthermore, the number of studies reporting evidence of local adaptation in marine fish species is rapidly increasing (Conover et al. 2006), and its influence on otolith signatures and its implications for studies examining stock structure may need to be considered.

\section{Temporal differences}

Temporal differences in otolith signatures of adjacent year classes indicate that the natural tags are year-class specific. Therefore, these juvenile tags can only be used as baseline data when addressing questions involving the population structure of the adults from the same year class. Classification accuracies of fish using signatures from alternate years for the baseline data were low and inconsistent. Furthermore, differences observed in the 2003 and 2004 year classes showed that all 8 variables significantly fluctuated annually. Other studies investigating temporal trends in otolith signatures have reported similar temporal differences (Gillanders 2002b). Warner et al. (2005) reported interannual differences in $\mathrm{Mg}, \mathrm{Sr}$, and $\mathrm{Pb}$, but not in $\mathrm{Mn}$ and $\mathrm{Ba}$. They also reported higher classification accuracies in the second field season, suggesting that some years produce stronger spatial differences in signatures than others. Gillanders \& Kingsford (2000) also reported interannual differences in $\mathrm{Sr}, \mathrm{Mn}$, and $\mathrm{Ba}$ in estuaries in Australia. While the exact cause of these differences cannot be fully understood without a more thorough understanding of the factors influencing the chemical composition of otoliths, it is likely that these differences are largely due to interannual environmental differences. The mean summer water temperatures recorded on a NOAA buoy located off Montauk, NY $\left(40^{\circ} 15^{\prime} 1^{\prime \prime} \mathrm{N}, 73^{\circ} 9^{\prime} 59^{\prime \prime} \mathrm{W}\right)$ were warmer in $2004\left(22.7^{\circ} \mathrm{C}\right)$ than in $2003\left(21.0^{\circ} \mathrm{C}\right)$. Additionally, the NOAA's National Climatic Data Service annual precipitation report states that the northeast of the United States received more rain in the summer of 2004 than in 2003. Regardless of the underlying causes of such temporal differences, our results suggest that in most marine situations otolith studies need to be carried out on an annual basis and studies need to consider temporal effects.

\section{Implications}

Understanding population connectivity and structure of marine fishes is important for effective ecosystem-based management and ecological understanding. Many fish species are managed as single populations over large spatial areas, but recent studies identified significant genetic differences within subpopulations at smaller scales than traditional management units. For example, Newfoundland cod are managed as having a broad stock structure, contradictory to the evidence of the smaller stock structure shown in adult migration studies (Robichaud \& Rose 2001). Evidence of sub-populations and connectivity rates are important when considering such things as the re- 
silience of a population to fishing pressure and when designing marine protected areas. The amount of exchange between sub-populations can also affect colonization rates for new habitats. Thus, knowledge of population structure is essential when developing spatially explicit management plans. Additionally, population structure is important in evolutionary ecology studies examining local adaptation and the strength of natural selection. Since the potential for local adaptation can be diminished by high degrees of mixing, assuming high gene flow, otolith chemistry can be useful in examining connectivity. Before patterns of connectivity and population structure can be investigated, an appropriate tag must be developed. Here we demonstrated that the chemical signatures of juvenile Menidia menidia otoliths show significant spatial differences in coastal environments, thus allowing them to be useful as natural tags. These data provide the necessary information to allow the natal origins of adult $M$. menidia in the northeastern United States to be determined and potentially to reconstruct patterns of adult dispersal.

Acknowledgements. This work was funded by the National Science Foundation (Grant OCE-0425830 to D.O.C. and OCE-0134998 to S.R.T.) and the New York State Department of Environmental Conservation. B.D.W. was supported by the Woods Hole Oceanographic Institution Academic Programs Office. We thank past and present members of the Conover Laboratory, K. Able, S. Hagan, R. Hagan, J. Socrates, and J. FitzGerald for help with sample collections. We thank S. Birdwhistell and D. Ostermann for assistance with the otolith analyses, and S. Sanudo for use of laboratory space. We also thank R. Cerrato for helpful comments on the manuscript.

\section{LITERATURE CITED}

Ashford JR, Jones CM, Hofmann E, Everson I, Moreno C, Duhamel G, Williams R (2005) Can otolith elemental signatures record the capture site of Patagonian toothfish (Dissostichus eleginoides), a fully marine fish in the Southern Ocean? Can J Fish Aquat Sci 62:2832-2840

Bath GE, Thorrold SR, Jones CM, Campana SE, McLaren JW, Lam JWH (2000) Strontium and barium uptake in aragonitic otoliths of marine fish. Geochim Cosmochim Acta 64:1705-1714

Billerbeck JM, Schultz ET, Conover DO (2000) Adaptive variation in energy acquisition and allocation among latitudinal populations of the Atlantic silverside. Oecologia 122:210-219

Buck NJ, Gobler CJ, Sanudo-Wilhelmy SA (2005) Dissolved trace element concentrations in the East River-Long Island Sound system: relative importance of autochthonous versus allochthonous sources. Environ Sci Technol 39:3528-3537

Buckel JA, Sharack BL, Zdanowicz VS (2004) Effect of diet on otolith composition in Pomatomus saltatrix, an estuarine piscivore. J Fish Biol 64:1469-1484

Campana SE, Chouinard GA, Hanson JM, Frechet A (1999) Mixing and migration of overwintering Atlantic cod
(Gadus morhua) stocks near the mouth of the Gulf of St. Lawrence. Can J Fish Aquat Sci 56:1873-1881

Conover DO, Murawski SA (1982) Offshore winter migration of the Atlantic silverside, Menidia menidia. Fish Bull (Wash DC) 80:145-150

Conover DO, Present TMC (1990) Countergradient variation in growth-rate - compensation for length of the growingseason among Atlantic silversides from different latitudes. Oecologia 83:316-324

Conover DO, Ross MR (1982) Patterns in seasonal abundance, growth and biomass of the Atlantic silverside, Menidia menidia, in a New England estuary. Estuaries 5:275-286

Conover DO, Clarke LM, Munch SB, Wagner GN (2006) Spatial and temporal scales of adaptive divergence in marine fishes and the implications for conservation. J Fish Biol 69: 21-47

Cowen RK, Paris CB, Srinivasan A (2006) Scaling of connectivity in marine populations. Science 311:522-527

Dorval E, Jones CM, Hannigan R, van Montfrans J (2005) Can otolith chemistry be used for identifying essential seagrass habitats for juvenile spotted seatrout, Cynoscion nebulosus, in Chesapeake Bay? Mar Freshw Res 56:645-653

FitzGerald JL, Thorrold SR, Bailey KM, Brown AL, Severin KP (2004) Elemental signatures in otoliths of larval walleye pollock (Theragra chalcogramma) from the northeast Pacific Ocean. Fish Bull (Wash DC) 102:604-616

> Forrester GE, Swearer SE (2002) Trace elements in otoliths indicate the use of open-coast versus bay nursery habitats by juvenile California halibut. Mar Ecol Prog Ser 241: 201-213

Friedland KD, Reddin DG, Shimizu N, Haas RE, Youngson AF (1998) Strontium:calcium ratios in Atlantic salmon (Salmo salar) otoliths and observations on growth and maturation. Can J Fish Aquat Sci 55:1158-1168

Gillanders BM (2002a) Connectivity between juvenile and adult fish populations: Do adults remain near their recruitment estuaries? Mar Ecol Prog Ser 240:215-223

Gillanders BM (2002b) Temporal and spatial variability in elemental composition of otoliths: implications for determining stock identity and connectivity of populations. Can J Fish Aquat Sci 59:669-679

Gillanders BM, Kingsford MJ (1996) Elements in otoliths may elucidate the contribution of estuarine recruitment to sustaining coastal reef populations of a temperate reef fish. Mar Ecol Prog Ser 141:13-20

Gillanders BM, Kingsford MJ (2000) Elemental fingerprints of otoliths of fish may distinguish estuarine 'nursery' habitats. Mar Ecol Prog Ser 201:273-286

Griffin MPA, Valiela I (2001) $\delta^{15} \mathrm{~N}$ isotope studies of life history and trophic position of Fundulus heteroclitus and Menidia menidia. Mar Ecol Prog Ser 214:299-305

Hamer PA, Jenkins GP (2007) Comparison of spatial variation in otolith chemistry of two fish species and relationships with water chemistry and otolith growth. J Fish Biol 71: 1035-1055

Hamer PA, Jenkins GP, Gillanders BM (2003) Otolith chemistry of juvenile snapper Pagrus auratus in Victorian waters: natural chemical tags and their temporal variation. Mar Ecol Prog Ser 263:261-273

Hillebrand SF (1928) Fishes of Chesapeake Bay. Bull US Bur Fish 43:1-388

- Humphreys RL, Campana SE, DeMartini EE (2005) Otolith elemental fingerprints of juvenile Pacific swordfish Xiphias gladius. J Fish Biol 66:1660-1670

> Jones GP, Milicich MJ, Emslie MJ, Lunow C (1999) Selfrecruitment in a coral reef fish population. Nature 402: 802-804 
Kalish JM (1989) Otolith microchemistry — validation of the effects of physiology, age and environment on otolith composition. J Exp Mar Biol Ecol 132:151-178

Kalish JM (1991a) ${ }^{13} \mathrm{C}$ and ${ }^{18} \mathrm{O}$ isotopic disequilibria in fish otoliths: metabolic and kinetic effects. Mar Ecol Prog Ser 75:191-203

Kalish JM (1991b) Determinants of otolith chemistry: seasonal variation in the composition of blood plasma, endolymph and otoliths of bearded rock cod Pseudophycis barbatus. Mar Ecol Prog Ser 74:137-159

Kennedy BP, Blum JD, Folt CL, Nislow KH (2000) Using natural strontium isotopic signatures as fish markers: methodology and application. Can J Fish Aquat Sci 57:2280-2292

Krzanowski WJ (1988) Principles of multivariate analysis. Oxford University Press, New York

Martin GB, Thorrold SR, Jones CM (2004) Temperature and salinity effects on strontium incorporation in otoliths of larval spot (Leiostomus xanthurus). Can J Fish Aquat Sci 61: $34-42$

Middaugh DP (1981) Reproductive ecology and spawning periodicity of the Atlantic silverside, Menidia menidia (Pisces, Atherinidae). Copeia 766-776

Middaugh DP, Scott GI, Dean JM (1981) Reproductive behavior of the Atlantic silverside, Menidia menidia (Pisces, Atherinidae). Environ Biol Fishes 6:269-276

Miller MB, Clough AM, Batson JM, Vachet RW (2006) Transition metal binding to cod otolith protein. J Exp Mar Biol Ecol 329:135-143

> Ostermann DR, Curry WB (2000) Calibration of stable isotopic data: an enriched $\delta^{18} \mathrm{O}$ standard used for source gas mixing detection and correction. Paleoceanography 15:353-360

Patterson HM, Kingsford MJ, McCulloch MT (2004) Elemental signatures of Pomacentrus coelestis otoliths at multiple spatial scales on the Great Barrier Reef, Australia. Mar Ecol Prog Ser 270:229-239

Present TMC, Conover DO (1992) Physiological basis of latitudinal growth differences in Menidia menidia-variation in consumption or efficiency. Funct Ecol 6:23-31

Robichaud D, Rose GA (2001) Multiyear homing of Atlantic cod to a spawning ground. Can J Fish Aquat Sci 58:2325-2329

Rooker JR, Secor DH, Zdanowicz VS, Itoh T (2001) Discrimination of northern bluefin tuna from nursery areas in the Pacific Ocean using otolith chemistry. Mar Ecol Prog Ser 218:275-282

Rosenthal Y, Field PM, Sherrell RM (1999) Precise determination of element/calcium ratios in calcareous samples using sector field inductively coupled plasma mass spectrometry. Anal Chem 71:3248-3253

Sadovy Y, Severin KP (1992) Trace elements in biogenic aragonite - correlation of body growth rate and strontium levels in the otoliths of the white grunt, Haemulon plumieri (Pisces, Haemulidae). Bull Mar Sci 50:237-257

Sadovy Y, Severin KP (1994) Elemental patterns in red hind (Epinephelus guttatus) otoliths from Bermuda and Puerto

Editorial responsibility: Cynthia Jones,

Norfolk, Virginia, USA
Rico reflect growth rate, not temperature. Can J Fish Aquat Sci 51:133-141

Scheiner S (2001) MANOVA: multiple response variables and multispecies interactions. In: Scheiner SM, Gurevitch J (eds) Design and analysis of ecological experiments, 2nd edn. Oxford University Press, Oxford, p 99-115

Schwarcz HP, Gao Y, Campana S, Browne D, Knyf M, Brand U (1998) Stable carbon isotope variations in otoliths of Atlantic cod (Gadus morhua). Can J Fish Aquat Sci 55: 1798-1806

Sinclair DJ, Kinsley LPJ, McCulloch MT (1998) High resolution analysis of trace elements in corals by laser ablation ICP-MS. Geochim Cosmochim Acta 62:1889-1901

> Sturgeon RE, Willie SN, Yang L, Greenberg R and others (2005) Certification of a fish otolith reference material in support of quality assurance for trace element analysis. J Anal At Spectrom 20:1067-1071

> Swearer SE, Caselle JE, Lea DW, Warner RR (1999) Larval retention and recruitment in an island population of a coral-reef fish. Nature 402:799-802

Swearer SE, Shima JS, Hellberg ME, Thorrold SR and others (2002) Evidence of self-recruitment in demersal marine populations. Bull Mar Sci 70:251-271

Swearer SE, Forrester GE, Steele MA, Brooks AJ, Lea DW (2003) Spatio-temporal and interspecific variation in otolith trace-elemental fingerprints in a temperate estuarine fish assemblage. Estuar Coast Shelf Sci 56: 1111-1123

> Thorrold SR, Campana SE, Jones CM, Swart PK (1997) Factors determining $\delta^{13} \mathrm{C}$ and $\delta^{18} \mathrm{O}$ fractionation in aragonitic otoliths of marine fish. Geochim Cosmochim Acta 61: 2909-2919

Thorrold SR, Jones CM, Campana SE, McLaren JW, Lam JWH (1998a) Trace element signatures in otoliths record natal river of juvenile American shad (Alosa sapidissima). Limnol Oceanogr 43:1826-1835

Thorrold SR, Jones CM, Swart PK, Targett TE (1998b) Accurate classification of juvenile weakfish Cynoscion regalis to estuarine nursery areas based on chemical signatures in otoliths. Mar Ecol Prog Ser 173:253-265

> Thorrold SR, Latkoczy C, Swart PK, Jones CM (2001) Natal homing in a marine fish metapopulation. Science 291: 297-299

Thresher RE (1999) Elemental composition of otoliths as a stock delineator in fishes. Fish Res 43:165-204

Walther BD, Thorrold SR, Olney JE (2008) Geochemical signatures in otoliths record natal origins in American shad. Trans Am Fish Soc 137:57-69

Warner RR, Swearer SE, Caselle JE, Sheehy M, Paradis G (2005) Natal trace-elemental signatures in the otoliths of an open-coast fish. Limnol Oceanogr 50:1529-1542

> Yoshinaga J, Nakama A, Morita M, Edmonds JS (2000) Fish otolith reference material for quality assurance of chemical analyses. Mar Chem 69:91-97

Submitted: July 23, 2007; Accepted: January 12, 2009

Proofs received from author(s): May 13, 2009 